\title{
META ANALISIS EFFECT SIZE PENGARUH BAHAN AJAR IPA DAN FISIKA BERBASIS STEM TERHADAP HASIL BELAJAR SISWA
}

\author{
Nurul Izzah, Asrizal, Festiyed \\ Program Studi Magister Pendidikan Fisika, FMIPA Universitas Negeri Padang \\ Email: nurullizzah88@gmail.com
}

Diterima: 04 Februari 2021. Direvisi: 17 Maret 2021. Disetujui: 18 Maret 2021.

\begin{abstract}
Abstrak
Pembelajaran abad-21 menuntut guru untuk mengarahkan siswanya agar memiliki kreativitas dalam mengelola permasalahan sehari-hari. Salah satu metode yang tepat digunakan adalah dengan menerapkan STEM (Science, Technology, Engineering and Mathematics). Untuk menunjang keberhasilan integrasi prinsip-prinsip disiplin ilmu STEM, khususnya pada pembelajaran IPA dan Fisika maka diperlukan suatu bahan ajar. Penelitian ini menganalisis pengaruh bahan ajar berbasis STEM dalam pembelajaran IPA dan Fisika terhadap hasil belajar siswa yang ditentukan melalui Effect Size (ES). Data penelitian diperoleh dari 20 jurnal nasional dan internasional. Analisis didasarkan pada kategori jenjang pendidikan, jenis bahan ajar serta besarnya pengaruh terhadap hasil belajar siswa. Hasil penelitian menunjukan bahwa bahan ajar berbasis STEM akan lebih efektif jika dilakukan pada jenjang SMA dengan jenis bahan ajar buku. Hasil perhitungan juga diperoleh bahwa penggunaan bahan ajar berbasis STEM efektif dalam ketiga ranah hasil belajar, yaitu pengetahuan, keterampilan dan sikap.
\end{abstract}

Kata Kunci: Bahan Ajar, IPA dan Fisika, STEM

\begin{abstract}
21 st century learning requires teachers to direct their students to have creativity in managing daily problems. One method that is appropriate to use is to apply STEM (Science, Technology, Engineering and Mathematics). To support the successful integration of the principles of STEM disciplines, especially in science and physics learning, a teaching material is needed. This study analyzes the effect of STEM-based teaching materials in science and physics learning on student learning outcomes which is determined by the Effect Size (ES). Research data were obtained from 20 national and international journals. The analysis is based on the category of education level, the type of teaching material and the amount of influence on student learning outcomes. The results showed that STEM-based teaching materials would be more effective if done at the high school level with the type of book teaching materials. The results of the calculation also show that the use of STEM-based teaching materials is effective in the three domains of learning outcomes, namely knowledge, skills and attitudes.
\end{abstract}

Keywords: Teaching Materials, Science and Physics, STEM. 
Izzah et al. - Analisis Effect Size Pengaruh ...

\section{PENDAHULUAN}

Belajar di abad 21 harusnya konteks, terkait dengan kehidupan komunitas, berpusat pada siswa dan kolaboratif (Asrizal, Amran, Ananda, Festiyed, \& Sumarmin, 2018). Lulusan pendidikan harus memiliki kompetensi yang baik untuk bersaing di abad 21 (Asrizal, Amran, Ananda, \& Festiyed, 2018). Guru harus memiliki kemampuan untuk mengembangkan pengajaran materi divariasikan sehingga pembelajaran tidak monotan dan tidak membosankan bagi siswa (Amila, Abdurrahman, Suyatna, Wayan, \& Herlina, 2018). Guru diharapkan dapat menyediakan pengalaman belajar yang beragam baik mental, fisik dan sosial (Festiyed, 2013). Di Indonesia saat ini diterapkan kurikulum 2013. Diterapkan kurikulum 2013 diharapkan dapat mengimplementasi-kan pembelajaran yang sesuai dengan tuntutan abad 21 .

Kurikulum 2013 mensyaratkan pembelajaran harus respontif terhadap perkembangan ilmu pengetahuan, budaya, teknologi, dan seni untuk membangun rasa ingin tahu dan kemampuan siswa (Kemendikbud,
2014). Kurikulum hanya 'basic material' bukan 'fixed price', artinya guru berhak untuk berkreasi dalam mengembangkan komponen kompetensi relevansi (Rokhman \& Yuliati, 2010). Pembelajaran abad-21 menuntut guru untuk mengarahkan siswanya agar berkreasi mengelola permasalahan sehari-hari. Salah satu pendekatan pembelajaran saat ini yang sangat mendukung tercapainya kompetensi abad 21 adalah pembelajaran berbasis STEM (Oktavia, 2020).

Pendekatan STEM (Science, Technology, Engineering and Mathematics) mengacu pada pengajaran dan pembelajaran di bidang sains, teknologi, teknik, dan matematika. Tujuan STEM adalah untuk mengembangkan pengetahuan, pemahaman konseptual, kemampuan berpikir kritis, menyiapkan guru untuk berperan dalam sejumlah lapangan kerja yang terkait dengan STEM, mengajak peserta didik untuk berkontribusi dalam perkembangan ekonomi, pemahaman tentang diri sendiri dan dunia (Neolaka \& Amalia, 2017). Sifat disiplin ilmu dan mekanisme yang terlibat tentang 
Izzah et al. - Analisis Effect Size Pengaruh ...

bagaimana disiplin itu terhubung perlu dibuat eksplisit dalam kurikulum dan pembelajaran STEM. Proses dan praktik pembelajaran STEM itu kompleks dan bermacammacam (Gao, Li, Shen, \& Sun, 2020). Pembelajaran terjadi melalui interaksi manusia ke manusia dan manusia ke lingkungan (Akbari, Kurnia, Anggraeni, \& Sri, 2018). Pembelajaran difasilitasi ketika peserta didik memanfaatkan setidaknya tiga organ indera yaitu; melihat, mendengar dan menyentuh (Rabiat, 2017).

Empat aspek STEM memiliki ciriciri khusus yang membedakan satu sama lain, akan tetapi keempatnya saling melengkapi satu sama lain. Efektivitas pengajaran dapat ditingkatkan hanya jika fungsi sistem kaya dan beragam sehingga dekat dengan persepsi pengguna dan menarik siswa untuk masuk ke sistem belajar (Lin, Chen, \& Liu, 2017). Pembelajaran STEM mampu melatih siswa menyelesaikan masalah kompleks yang menyerupai masalah di dunia nyata secara kritis dan kreatif. Praktik seperti ini tentunya melatih berbagai keterampilan abad
21 seperti keterampilan pemecahan masalah, berpikir kritis, berfikir kreatif dan kolaborasi (Fatmawati, Ariesta, Yunita, Darmaji, \& Rosa, 2015).

STEM merupakan salah satu reformasi dalam pendidikan (Bybee, 2013). STEM dinilai sangat tepat dilaksanakan saat ini. Siswa dituntut menguasai keterampilan di bidang sains, teknologi, teknik dan matematika. Melalui pendidikan berbasis STEM, siswa akan memiliki pola pikir yang logis, sistematis, serta kritis. Hal tersebut tentunya akan membawa dampak yang baik dalam pembelajaran, termasuk pembelajaran IPA dan Fisika.

Pembelajaran sains harus memberikan pengalaman proses ilmiah yang baik dan meningkatkan keterampilan berpikir tingkat tinggi pada siswa (Asrizal, Hendri, Hidayati, \& Festiyed, 2018). IPA (Ilmu Pengetahuan Alam) adalah memahami pengertian ilmu alam itu sendiri. Fisika adalah salah satu bagian dari ilmu alam (Ngadinem \& Sulisworo, 2020). Fisika merupakan ilmu pengetahuan alam yang mempelajari unsur-unsur dasar 
Izzah et al. - Analisis Effect Size Pengaruh ...

pembentuk alam semesta, gaya-gaya yang bekerja didalamnya, dan akibatakibatnya.

Untuk menunjang keberhasilan interdisiplin STEM, khususnya pada pembelajaran IPA dan Fisika maka diperlukan suatu bahan ajar. Bahan ajar merupakan seperangkat materi yang disusun secara sistematis, baik tertulis maupun tidak, sehingga tercipta lingkungan atau suasana yang memungkinkan siswa untuk belajar (Prastowo, 2019). Salah satu faktor yang mempengaruhi prestasi akademik siswa adalah ketersediaan bahan ajar yang memadai (Prabowo, Rahmawati, \& Puput, 2019). Menulis bahan ajar fisika berbeda dengan menulis karangan dalam pelajaran bahasa. Menguasai kemampuan menulis bahan ajar fisika, seperti modul, catatan pelajaran, penuntun praktikum dan buku teks sangat penting (Sinaga, Suhandi, \& Liliasari, 2015). Jenis bahan ajar berdasarkan pembelajaran terdiri dari ; (i) bahan ajar yang sengaja dirancang untuk pembelajaran seperti buku, handout, lembar kerja dan modul siswa, (ii) bahan ajar yang tidak dirancang tetapi dapat digunakan untuk pembelajaran seperti koran, film, atau iklan (Widayanti, Abdurrahman, \& A., 2019). Bahan ajar harus : i) sederhana, gamblang, dan mudah dimengerti, ii) mencerminkan kehidupan nyata, dan iii) mudah dikembangkan atau direvisi, jika perlu (Aydin \& Aytekin, 2018). Suatu bahan ajar harus dapat memberikan kesempatan kepada siswa belajar secara efektif dan guru mengajar secara efisien untuk mencapai suatu kompetensi yang diharapkan berdasarkan kurikulum (Hustarna \& Melati, 2019).

Pentingnya penggunaan bahan ajar sangat menentukan proses pembelajaran bermutu. Menurut (Fitria, 2017) masih banyak siswa yang mendapatkan nilai IPA dibawah KKM. Solusi dari persoalan tersebut adalah dengan merancang bahan ajar yang sesuai. Bahan ajar dapat meningkatkan hasil belajar (Ginting, 2012). Integrasi aspek-aspek STEM kedalam suatu bahan ajar dapat mendukung peningkatan hasil belajar. Hal ini sesusai dengan penelitian (Becker \& Park, 2011) yang membuktikan bahwa STEM dapat memberikan dampak positif untuk 
Izzah et al. - Analisis Effect Size Pengaruh ...

peningkatan pencapaian belajar Size dalam penelitian-penelitian dibidang sains maupun teknologi.

Atas dasar hal tersebut, maka perlu analisis effect size pengaruh bahan ajar IPA dan Fisika berbasis STEM terhadap hasil belajar siswa. Rumusan masalah penelitian ini adalah bagaimana pengaruh penggunaan bahan ajar IPA dan Fisika berbasis STEM terhadap hasil belajar siswa yang ditinjau dari jenjang pendidikan, jenis bahan ajar dan ranah hasil belajar. Tujuan dari penelitian ini ada tiga. Pertama, untuk melihat seberapa besar pengaruh yang diberikan oleh penggunaan bahan ajar IPA dan Fisika berbasis STEM ditinjau dari jenjang pendidikan. Kedua, untuk melihat seberapa besar pengaruh yang diberikan oleh penggunaan bahan ajar IPA dan Fisika berbasis STEM ditinjau dari jenis bahan ajar. Ketiga, untuk melihat seberapa besar pengaruh yang diberikan oleh penggunaan bahan ajar IPA dan Fisika berbasis STEM terhadap hasil belajar siswa.

\section{METODE}

Penelitian ini merupakan studi literature tentang gambaran Effect

pendidikan. Pertama, menetapkan rumusan masalah. Adapun rumusan masalah pada penelitian ini adalah pengaruh penggunaan bahan ajar IPA dan Fisika berbasis STEM terhadap hasil belajar siswa. Kedua, peneliti mengumpulkan dan memilih jurnal yang relevan dengan topik yang akan diteliti. Topik yang diteliti disesuaikan dengan rumusan masalah penelitian ini. Ketiga, dihitung besar Effect Size dari setiap jurnal yang relevan. Perhitungan diperoleh dari rumus yang sesuai dengan data yang diberikan jurnal. Keempat, Effect Size-nya dirata-ratakan dan dikategorikan sesuai dengan variabel moderator yang ingin dilihat ukuran pengaruhnya. Kelima, membuat kesimpulan dari penelitian deskriptif ini secara sederhana dan menyeluruh.

Effect size didefinisikan sebagai besarnya efek antara dua atau lebih variabel yang dinyatakan dalam $f$ atau ES. Adapun cara memperoleh nilai ES disajikan dalam Tabel 1, dan Ukuran efek dikategorikan pada tingkatan menurut Cohen's ditunjukkan pada tabel 2 . 
Izzah et al. - Analisis Effect Size Pengaruh ...

Tabel 1 : Cara menentukan besarnya Effect Size

\begin{tabular}{|c|c|c|c|}
\hline No & Data Statistik & Rumus & Formula \\
\hline 1 & $\begin{array}{l}\text { Rata-rata pada satu } \\
\text { kelompok }\end{array}$ & $E S=\frac{\bar{X}_{\text {post }}-\bar{X}_{\text {pre }}}{S D_{\text {pre }}}$ & Fr-1 \\
\hline 2 & $\begin{array}{l}\text { Rata-rata pada masing- } \\
\text { masing kelompok (two } \\
\text { groups posttest only) }\end{array}$ & $E S=\frac{\bar{X}_{E}-\bar{X}_{C}}{S D_{C}}$ & Fr-2 \\
\hline 3 & $\begin{array}{l}\text { Rata-rata pada masing- } \\
\text { masing kelompok (two } \\
\text { groups pre-post tests) }\end{array}$ & $E S=\frac{\left(\bar{X}_{\text {post }}-\bar{X}_{\text {pre }}\right)_{E}-\left(\bar{X}_{\text {post }}-\bar{X}_{\text {pre }}\right)_{C}}{\frac{S D_{\text {prec }}+S D_{\text {preE }}+S D_{\text {postC }}}{3}}$ & Fr-3 \\
\hline 4 & Chi-Square & $E S=\frac{2 r}{\sqrt{1-r^{2}}} ; \sqrt{\frac{\chi^{2}}{n}}$ & Fr-4 \\
\hline 5 & t hitung & $E S=t \sqrt{\frac{1}{n_{E}}+\frac{1}{n_{C}}}$ & Fr-5 \\
\hline 6 & Nilai $\mathrm{P}$ & CMA (Comperhensive Meta Analisis Software) & Fr-6 \\
\hline
\end{tabular}

(Becker \& Park, 2011)

Tabel 2 : Kategori Effect Size

\begin{tabular}{cc}
\hline Effect Size & Kategori \\
\hline $0 \leq \mathrm{ES} \leq 0,2$ & Rendah \\
$0,2 \leq \mathrm{ES} \leq 0,8$ & Sedang \\
$\mathrm{ES} \geq 0,8$ & Tinggi \\
\hline
\end{tabular}

(Cohen, 1988)

\section{HASIL DAN PEMBAHASAN}

Penelitian ini dilakukan untuk melihat pengaruh bahan ajar IPA dan fisika berbasis STEM terhadap hasil belajar siswa dengan meninjau dan menganalisis dari beberapa variabel moderator. Data diperoleh dari jurnaljurnal yang relevan dengan penelitian ini serta mendukung untuk dilakukan perhitungan effect size dari setiap jurnal. Peneliti mengumpulkan data dari berbagai sumber seperti Google Scholar, Journal of Physics, EURASIA Journal of Mathematics Science and Technology Education, dan lain-lain.

Sebanyak 20 jurnal dipilih berdasarkan kriteria tertentu. Pertama merupakan penelitian mengenai bahan ajar cetak ataupun non cetak, kedua berbasis pendekatan STEM dan ketiga diimplementasikan pada pembelajaran 
Izzah et al. - Analisis Effect Size Pengaruh ...

IPA atau Fisika. Jenis jurnal berasal pendidikan. Selanjutnya kedua, dari jurnal nasional dan internasional. berdasarkan jenis bahan ajar. Ketiga,

Hasil yang diperoleh dari berdasarkan ranah hasil belajar yang perhitungan effect size ke 20 jurnal diperoleh oleh siswa. Kodifikasi diatas, digolongkan menjadi tiga artikel dapat dilihat pada tabel 3. bagian. Pertama, berdasarkan jenjang

Tabel 3 : Kode, Sumber Jurnal, Effect Size dan Formula yang digunakan

\begin{tabular}{clcc}
\hline Kode & \multicolumn{1}{c}{ Sumbe Jurnal } & Effect Size & Formula \\
\hline J1 & (Adlim, Saminan, \& Ariestia, 2015) & 1,21 & Fr-5 \\
J2 & (A'yun, Rusilowati, \& Lisdiana, & 0,43 & Fr-5 \\
J3 & (Shahali et al., 2017) & 0,5 & Fr-1 \\
J4 & (Harjo \& Mosik, 2019) & 2,2 & Fr-1 \\
J5 & (Yuli, 2019) & 2,89 & Fr-5 \\
J6 & (Indrasari, Parno, Hidayat, & 1,34 & Fr-2 \\
J7 & (Kuswaningsih, \& Herlina, 2020) & 5,1 & Fr-5 \\
J8 & Suyatna, 2019) & 0,84 & Fr-5 \\
J9 & (Mohanama \& Kinasih, 2020) $\&$ Osman, 2019) & 0,1 & Fr-5 \\
J10 & (Mohamad, Osman, \& Amin, 2017) & 0,21 & - \\
J11 & (Moi \& Ambo, 2018) & 3,04 & Fr-3 \\
J12 & (Ozcam \& Koca, 2019) & 1,59 & - \\
J13 & (Puspita, 2019) & 0,9 & Fr-3 \\
J14 & (Putri, Rusdiana, \& Rahma, 2019) & 1,43 & Fr-2 \\
J15 & (Rahmiza, Adlim, \& Mursal, 2015) & 5,01 & Fr-5 \\
J16 & (Roth et al., 2017) & 0,68 & - \\
J17 & (Standish et al., 2016) & 1,18 & - \\
J18 & (Sulistiyowati, Abdurrahman, \& & 0,7 & Fr-3 \\
J19 & (Taufiq, Muntamah, \& Parmin, & 2,7 & Fr-5 \\
J20 & (Widoyoko, Latifah, \& Yulianti, & 1,34 & Fr-2 \\
\hline & 2018) & & \\
\hline
\end{tabular}


Izzah et al. - Analisis Effect Size Pengaruh ...

Pengaruh Bahan Ajar IPA dan Fisika Berbasis STEM Berdasarkan Jenjang Pendidikan

Hasil pertama dalam penelitian ini bahan ajar berbasis STEM terhadap hasil belajar ditinjau dari jenjang pendidikan. Perhitungan yang diperoleh disajikan dalam Tabel 4. terkait analisis effect size pengaruh

Tabel 4 : Effect Size Bahan Ajar Berbasis STEM Berdasarkan Jenjang Pendidikan

\begin{tabular}{|c|c|c|c|c|}
\hline Jenjang Pendidikan & $\begin{array}{c}\text { Kode } \\
\text { Jurnal }\end{array}$ & Effect Size & Rata-rata Ukuran Efek & Kategori \\
\hline \multirow{5}{*}{ SD } & J5 & 2,89 & \multirow{5}{*}{1,73} & \multirow{5}{*}{ Tinggi } \\
\hline & J9 & 0,1 & & \\
\hline & $\mathrm{J} 10$ & 0,21 & & \\
\hline & $\mathrm{J} 11$ & 3,04 & & \\
\hline & $\mathrm{J} 16$ & 0,68 & & \\
\hline \multirow{8}{*}{ SMP } & $\mathrm{J} 2$ & 0,43 & \multirow{8}{*}{1,63} & \multirow{8}{*}{ Tinggi } \\
\hline & $\mathrm{J} 3$ & 0,5 & & \\
\hline & $\mathrm{J} 7$ & 5,1 & & \\
\hline & J8 & 0,84 & & \\
\hline & $\mathrm{J} 12$ & 1,59 & & \\
\hline & $\mathrm{J} 17$ & 1,18 & & \\
\hline & $\mathrm{J} 18$ & 0,7 & & \\
\hline & $\mathrm{J} 19$ & 2,7 & & \\
\hline \multirow{7}{*}{ SMA } & $\mathrm{J} 1$ & 1,21 & \multirow{7}{*}{1,9} & \multirow{7}{*}{ Tinggi } \\
\hline & $\mathrm{J} 4$ & 2,2 & & \\
\hline & J6 & 1,34 & & \\
\hline & $\mathrm{J} 13$ & 0,9 & & \\
\hline & $\mathrm{J} 14$ & 1,43 & & \\
\hline & $\mathrm{J} 15$ & 5,01 & & \\
\hline & $\mathrm{J} 20$ & 1,34 & & \\
\hline
\end{tabular}

Dari perhitungan Effect Size kategori effect size tinggi untuk pengaruh bahan ajar berbasis STEM jenjang Sekolah Menengah Pertama; terhadap pembelajaran IPA dan Fisika $\mathrm{ES}=1,9$ dengan kategori effect size berdasarkan jenjang pendidikan, tinggi untuk jenjang Sekolah diperoleh ES=1,73 dengan kategori Menengah Atas.

effect size tinggi untuk jenjang Analisis berdasarkan jenjang Sekolah Dasar; ES=1,63 dengan pendidikan diperoleh bahwa bahan 
Izzah et al. - Analisis Effect Size Pengaruh ...

ajar berbasis STEM efektif digunakan di SMA dibandingkan dengan SD dan SMP. Namun, ketiga jenjang pendidikan SD, SMP dan SMA memiliki Effect Size dengan kategori yang tinggi. Effect Size tertinggi pengaruh bahan ajar berbasis STEM adalah di SMA. Hal ini menunjukan bahwa bahan ajar berbasis STEM sangat efektif digunakan di semua jenjang pendidikan dalam pembelajaran IPA maupun Fisika, terutama di SMA.

Menurut (Andesta, 2018) pada usia 11-12 tahun keatas anak mengalami fase operasional formal, yaitu fase dimana anak sudah dapat memikirkan sesuatu yang akan atau mungkin terjadi (hipotesis) dan sesuatu bersifat abstrak. Dalam proses KBM anak pada fase ini sudah bisa diterapkan pembelajaran dengan berbagai model untuk penalaran tinggi serta menuntut anak untuk aktif berfikir, beride dan menarik makna dari hal yang empirik maupun abstrak. Hal ini sesuai dengan konsep pembelajaran fisika dan IPA yang bersifat abstrak. Pernyataan tersebut sesuai dengan temuan Effect Size yang telah dikaji peneliti. Dari
Tabel 4 terlihat bahwa jenjang SMA memiliki efek tertinggi penggunaan bahan ajar berbasis STEM pada pembelajaran IPA dan Fisika.

\section{Pengaruh Bahan Ajar IPA dan} Fisika Berbasis STEM Berdasarkan

\section{Jenis Bahan Ajar}

Hasil kedua dalam penelitian ini terkait analisis effect size pengaruh bahan ajar berbasis STEM terhadap hasil belajar ditinjau dari jenis bahan ajar. Perhitungan yang diperoleh disajikan dalam Tabel 5.

Dari perhitungan Effect Size pengaruh bahan ajar berbasis STEM terhadap pembelajaran IPA dan Fisika berdasarkan jenis bahan ajar, diperoleh $\mathrm{ES}=1,12$ dengan kategori effect size tinggi untuk bahan ajar modul; ES=2,1 dengan kategori effect size tinggi untuk bahan ajar LKS/LKPD; ES=3,25 dengan kategori effect size tinggi untuk bahan ajar buku; $\mathrm{ES}=0,84$ dengan kategori effect size tinggi untuk bahan ajar handout; $\mathrm{ES}=0,68$ dengan kategori effect size sedang untuk bahan ajar video; dan $\mathrm{ES}=1,34$ dengan kategori effect size tinggi untuk bahan ajar. 
Izzah et al. - Analisis Effect Size Pengaruh ...

Tabel 5 : Effect Size Bahan Ajar Berbasis STEM Berdasarkan Jenis Bahan Ajar

\begin{tabular}{|c|c|c|c|c|}
\hline Jenis Bahan Ajar & $\begin{array}{c}\text { Kode } \\
\text { Jurnal }\end{array}$ & Effect Size & Rata-rata Ukuran Efek & Kategori \\
\hline \multirow{7}{*}{ Modul } & $\mathrm{J} 1$ & 1,21 & \multirow{7}{*}{1,12} & \multirow{7}{*}{ Tinggi } \\
\hline & $\mathrm{J} 3$ & 0,5 & & \\
\hline & J9 & 0,1 & & \\
\hline & $\mathrm{J} 10$ & 0,21 & & \\
\hline & $\mathrm{J} 11$ & 3,04 & & \\
\hline & $\mathrm{J} 12$ & 1,59 & & \\
\hline & $\mathrm{J} 17$ & 1,18 & & \\
\hline \multirow{6}{*}{ LKS/LKPD } & $\mathrm{J} 4$ & 2,2 & \multirow{6}{*}{2,1} & \multirow{6}{*}{ Tinggi } \\
\hline & $\mathrm{J} 13$ & 0,9 & & \\
\hline & $\mathrm{J} 14$ & 1,43 & & \\
\hline & $\mathrm{J} 15$ & 5,01 & & \\
\hline & $\mathrm{J} 18$ & 0,7 & & \\
\hline & $\mathrm{J} 19$ & 2,7 & & \\
\hline \multirow{4}{*}{ Buku } & $\mathrm{J} 2$ & 0,43 & \multirow{4}{*}{3,25} & \multirow{4}{*}{ Tinggi } \\
\hline & $\mathrm{J} 5$ & 2,89 & & \\
\hline & $\mathrm{J} 6$ & 1,34 & & \\
\hline & $\mathrm{J} 7$ & 5,1 & & \\
\hline Handout & $\mathrm{J} 8$ & 0,84 & 0,84 & Tinggi \\
\hline Video & $\mathrm{J} 16$ & 0,68 & 0,68 & Sedang \\
\hline Bahan Ajar & $\mathrm{J} 20$ & 1,34 & 1,34 & Tinggi \\
\hline
\end{tabular}

Analisis pengaruh bahan ajar pembelajaran itu sendiri yang berbasis STEM berdasarkan jenis diperoleh dari respon siswa selama bahan ajar diperoleh efek yang tinggi proses pembelajaran. Salah satu hal untuk jenis bahan ajar modul, yang dapat meningkatkan LKS/LKPD, buku dan handout. pembelajaran yaitu melalui Sedangkan untuk jenis bahan ajar penggunaan sumber belajar terutama video diperoleh kategori sedang. Efek buku (Azura \& Octarya, 2020). Buku tertinggi berdasarkan jenis bahan ajar adalah salah satu dari jenis bahan ajar adalah pada buku.

Dalam pendidikan, proses sumber belajar. Alasan dari pembelajaran di kelas sangat penggunaan buku yaitu besarnya nilai bergantung pada faktor yang keterpakaian pada buku yang dapat mempengaruhi kualitas proses memenuhi kebutuhan dua pihak, yaitu 
Izzah et al. - Analisis Effect Size Pengaruh ...

guru dan siswa Berdasarkan temuan peneliti penggunaan bahan ajar buku berbasis STEM memberikan efek tertinggi pada pembelajaran IPA dan Fisika.

Pengaruh Bahan Ajar IPA dan Fisika Berbasis STEM Terhadap Hasil Belajar Siswa
Hasil ketiga dalam penelitian ini terkait analisis effect size pengaruh bahan ajar berbasis STEM terhadap hasil belajar yang dikategorikan ke dalam tiga ranah hasil belajar. Perhitungan yang diperoleh disajikan dalam Tabel 6.

Tabel 6. Effect Size Bahan Ajar IPA dan Fisika Berbasis STEM Terhadap Hasil Belajar Siswa

\begin{tabular}{|c|c|c|c|c|}
\hline Hasil Belajar & $\begin{array}{c}\text { Kode } \\
\text { Jurnal }\end{array}$ & Effect Size & Rata-rata Ukuran Efek & Kategori \\
\hline \multirow{7}{*}{ Pengetahuan } & J5 & 2,89 & \multirow{7}{*}{1,9} & \multirow{7}{*}{ Tinggi } \\
\hline & $\mathrm{J} 7$ & 5,1 & & \\
\hline & $\mathrm{J} 8$ & 0,84 & & \\
\hline & J9 & 0,1 & & \\
\hline & $\mathrm{J} 16$ & 0,68 & & \\
\hline & $\mathrm{J} 17$ & 1,18 & & \\
\hline & $\mathrm{J} 19$ & 2,7 & & \\
\hline \multirow{10}{*}{ Keterampilan } & $\mathrm{J} 1$ & 1,21 & \multirow{10}{*}{1,32} & \multirow{10}{*}{ Tinggi } \\
\hline & $\mathrm{J} 2$ & 0,43 & & \\
\hline & $\mathrm{J} 3$ & 0,5 & & \\
\hline & $\mathrm{J} 4$ & 2,2 & & \\
\hline & J6 & 1,43 & & \\
\hline & $\mathrm{J} 11$ & 3,04 & & \\
\hline & $\mathrm{J} 13$ & 0,9 & & \\
\hline & $\mathrm{J} 14$ & 1,43 & & \\
\hline & $\mathrm{J} 18$ & 0,7 & & \\
\hline & $\mathrm{J} 20$ & 1,34 & & \\
\hline \multirow{3}{*}{ Sikap } & $\mathrm{J} 10$ & 0,21 & \multirow{3}{*}{2,27} & \multirow{3}{*}{ Tinggi } \\
\hline & $\mathrm{J} 12$ & 1,59 & & \\
\hline & $\mathrm{J} 15$ & 5,01 & & \\
\hline
\end{tabular}

Dari perhitungan Effect Size diperoleh ES=1,9 dengan kategori pengaruh bahan ajar IPA dan Fisika effect size tinggi untuk ranah berbasis STEM terhadap hasil belajar, pengetahuan; $\mathrm{ES}=1,32$ dengan 
Izzah et al. - Analisis Effect Size Pengaruh ...

kategori effect size tinggi untuk ranah keterampilan; $\mathrm{ES}=2,27$ dengan kategori effect size tinggi untuk ranah sikap.

Selanjutnya effect size bahan ajar IPA dan Fisika berbasis STEM terhadap hasil belajar siswa. Hasil belajar terdiri dari tiga ranah, yaitu ranah pengetahuan, ranah keterampilan dan ranah sikap. Dari perhitungan diperoleh bahwa penggunaan bahan ajar berbasis STEM efektif digunakan dalam ketiga ranah, terutama pada ranah sikap. Hal ini sesuai dengan pendapat (Sukma, 2018), yang menyatakan bahwa pendekatan pembelajaran STEM dapat memengaruhi penilaian autentik siswa terdiri dari aspek kognitif, afektif dan psikomotor.

\section{KESIMPULAN DAN SARAN}

\section{Kesimpulan}

Berdasarkan data yang telah dinyatakan dalam penelitian ini maka dapat dinyatakan tiga hasil dalam penelitian ini. Pertama pengaplikasian bahan ajar IPA dan fisika berbasis STEM akan lebih efektif jika dilakukan pada jenjang SMA. Kedua dari subjek jenis bahan ajar akan lebih efektif jika diaplikasikan dalam buku IPA dan Fisika berbasis STEM. Ketiga bahan ajar IPA dan fisika berbasis STEM memberikan pengaruh yang efektif pada hasil belajar siswa baik ranah pengetahuan, keterampilan maupun sikap.

\section{Saran}

Guru harus mampu mengembangkan suatu bahan ajar yang mengintegrasikan disiplin ilm STEM didalamnya sebagai penunjang saat pembelajaran berlangsung.

\section{DAFTAR PUSTAKA}

Adlim, M., Saminan, \& Ariestia, S. (2015). Pengembangan Modul STEM Terintegrasi Kewirausahaan untuk Meningkatkan Keterampilan Proses Sains Di SMA Negeri 4 Bada Aceh. Jurnal Pendidikan Sains Indonesia, 3(2), 112-121.

Akbari, S., Kurnia, N. S., Anggraeni, D. S., \& Sri, M. H. (2018). Design of Teaching and Learning Materials based on the Values of Local Heroic Struggle in Sukoharjo. International Journal of Multicultural and Multireligious Understanding, 5(6), 28-33.

Amila, A. w., Abdurrahman, Suyatna, A., Wayan, I. D., \& Herlina, K. (2018). Practicallity and Affectiveness of Student' Worksheets Based on Ethno Science to Improve Conceptual Understanding in Rigid Body. 
Izzah et al. - Analisis Effect Size Pengaruh ...

International Journal of Advanced Enginering, Management and Science, 4(5), 400-407.

Andesta, D. B. (2018). Analisis Perkembangan Kognitif Anak Usia Dasar dan Implikasinya dalam Kegiatan Belajar Mengajar. Jornal homepage:

www.ejournal.almaata.ac.id/litera si, 9(1), 37-50.

Asrizal, Amran, Ananda, \& Festiyed. (2018). Effectiveness of Adaptive Contextual Learning Model of Integrated Science by Integrating Digital Age Literacy on Grade VIII Students. IOP Conference Series: Materials Science and Engineering (hal. 1-8). Padang: IOP Publishing.

Asrizal, Amran, Ananda, Festiyed, \& Sumarmin. (2018). The Development of Integrated Science Instructional Materials to Improve Students Digital Literacy in Scientific Approach. Jurnal Pendidikan IPA Indonesia, 7(4), 442-450.

Asrizal, Hendri, A., Hidayati, \& Festiyed. (2018). Penerapan Model Pembelajaran Penemuan Mengintegrasikan Laboratorium Virtual dan Hots untuk Meningkatkan Hasil Pembelajaran Siswa SMA Kelas XI. Prosiding Seminar Nasional Hibah Program Penugasan Dosen ke Sekolah (PDS) (hal. 49-57). Padang: Universitas Negeri Padang.

Aydin, A., \& Aytekin, C. (2018). Teaching Materials Development and Meeting the Needs of the Subject : A Sample Application.
International Education Studies, 11(8), 27-38.

A'yun, Q., Rusilowati, A., \& Lisdiana. (2020). Improving Students' Critical Thinking Skills Through The STEM Digital Book. Journal of Innovative Science Education, 9(2), 237-243.

Azura, \& Octarya, Z. (2020). Desain dan Uji Coba Buku Ajar Berbasis Science, Technology, Engineering and Mathematics (STEM) pada Materi Asam Basa. Journal Education and Chemistry, 2(1), 32-38.

Becker, K., \& Park, K. (2011). Effects of Integrative Approaches Among Science, Technology, Engineering and Mathematics (STEM) Subjects on Students' Learning : A Preliminary MetaAnalysis. Journal of STEM Education, 12(5\&6), 23-37.

Bybee, R. W. (2013). The Case for STEM Education Challanges and Opportunities. Amerika: NSTA Press.

Cohen, J. (1988). Statistical Power Analysis for The Behavior Science (2nd ed.). Hillsdale, NJ: Lawrance Earlbaum Associations.

Fatmawati, S., Ariesta, N., Yunita, L. S., Darmaji, \& Rosa, S. P. (2015). Desain Laboratorium Skala Mini untuk Pembelajaran Terpadu. Yogyakarta: Deepublish.

Festiyed. (2013). Perubahan Paradigma Proses Pembelajaran dalam Memberikan Layanan Profesional Berbasis Karakter. Seminar Nasional MIPA dan 
Izzah et al. - Analisis Effect Size Pengaruh ...

PMIPA IAIN Sulthan Thaha

Saifuddin Jambi, (hal. 1-27).

Fitria, Y. (2017). Development of Problem-Based Teaching Materials for The Fifth Graders of Primary School. Jurnal Ta'dib, 20 (2), 99106.

Gao, X., Li, P., Shen, J., \& Sun, H. (2020). Reviewing Assesment of Student Learning in Interdisciplinary STEM Education. International Journal of STEM Education, 7(24), 1-14.

Ginting, R. U. (2012). Efektivitas Penggunaan Bahan Ajar dan Belajar Mandiri dalam Rangka Peningkatan Hasil Belajar Termodinamika Dasar. Jurnal Pendidikan Teknologi dan Kejuruan Fakultas Teknik Unimed, 14 (1), 1-6.

Harjo, S. S., \& Mosik. (2019). Keefektifan LKS Berbasis STEM (Science, Technology, Engineering and Mathematics) untuk Melatih Keterampilan Berpikir Kritis Siswa pada Pembelajaran Fisika SMA. Unnes Physics Education Journal, 8(3), 248-253.

Hustarna, \& Melati. (2019). Developing A Teacher Material Prototype for Linguistics Description of English Course. International Journal of Language Teaching and Education, 3(1), 110.

Indrasari, N., Parno, Hidayat, A., Puswaningsih, E., \& Herlina, W. (2020). Designing and Implementing STEM-based Teaching Materials of Static Fluid to Increase Scientific Literacy
Skills. AIP Conference Proceedings (hal. 2-8). Malang: AIP Publishing.

Kemendikbud. (2014). Konsep dan Implementasi Kurikulum 2013. Jakarta: Kementrian Pendidikan dan Kebudayaan.

Khoiriyah, N., Abdurrahman, \& Suyatna, A. (2019). Development of Comics Physics Education with STEM for Stimulating Straight Line Motion Concept Mastery in Junior High School Students. Jurnal Pembelajaran Fisika, 7(2), 77-85.

Lin, M.-H., Chen, H.-C., \& Liu, K.-S. (2017). A Study of the Effects of Digital Learning on Learning Motivation and Learning Outcome. EURASIA Journal of Mathematics, Science and Technology Education, 13(7), 3553-3564.

Mariana, E., \& Kinasih, A. (2020). Pengaruh Penggunaan Handout Terhadap Hasil Belajar Fisika Kelas VIII SMP N 3 Tumijajar. Jurnal Pendidikan Sains, 8(2), 171-178.

Mohamad, N. A., \& Osman, K. (2019). Penerapan Nilai Murni Melalui Interaksi T-A-M dan Kitaran Pengajaran 5E dalam Modul Tauhidik STEM Kids. Jurnal Pendidikan Malaysia, 44(1), 67-82.

Mohamad, N. A., Osman, K., \& Amin, M. E. (2017). Effect of STEM-5E Learning Cycle (AMSTEM Kids Module) in Foresting Noble Values Among Elementary School Children. The Eurasia Proceedings of Educational \& 
Izzah et al. - Analisis Effect Size Pengaruh ...

Social Sciences (hal. 160-166). Malaysia: ISRES Publishing.

Moi, N. S., \& Ambo, N. (2018). Development and Evaluation of An Integrated Project-Based and STEM Teaching and Learning Module on Enhancing Scientific Creativity Among Fifth Grades. Journal of Baltic Science Education, 17(6), 1017-1033.

Neolaka, A., \& Amalia, G. A. (2017). Landasan Pendidikan : Dasar Pengenalan Diri Sendiri Menuju Prubahan Hidup. Jakarta: Kencana.

Ngadinem, \& Sulisworo, D. (2020). The Improvement of Higher-Order Thinking Skills Through Project-Based Learning on STEM Education Settings. Proceedings of The International Conference on Community Development (hal. 504-507). Atlantis Press.

Oktavia, R. (2020). Bahan Ajar Berbasis Science, Technology, Engineering and Mathematics (STEM) untuk Mendukung Pembelajaran IPA Terpadu. Jurnal SEMESTA Pendidikan IPA, 32-36.

Ozcam, H., \& Koca, E. (2019). The Impact of Teaching the Subject "Pressure" with STEM Approach on The Academic Achievements of The Secondary School 7th Grade Students and Their Attitudes Towards STEM. Education and Science, 44(198), 201-227.

Prabowo, A., Rahmawati, U., \& Puput, R. A. (2019). Androidbased Teaching Material for Statistics Integrated with Social Media WhatsApp. International
Journal on Emerging Mathematics Education, 3(1), 93-104.

Prastowo, A. (2019). Pengembangan Bahan Ajar Tematik. Jakarta: Kencana.

Puspita, A. D. (2019). Implementasi Lembar Kerja Peserta Didik (LKPD) Berbasis Science, Technology, Engineering and Mathematics (STEM) pada Materi Usaha dan Energi untuk Meningkatkan Kemampuan Berpikir Kritis Di SMA Muhammadiyah 7 Yogyakarta. Jurnal Pendidikan Fisika Universitas Ahmad Dahlan, 1-11.

Putri, N., Rusdiana, D., \& Rahma, I. S. (2019). The Comparison of Student Creative Thinking Skill using CBL Implemented in STEM Education and Combined with PSL Worksheet in Indonsian School . Journa lof Science Learning, 3(1), 7-11.

Rabiat, A. A. (2017). The Importance of Instructional Materials in Teaching English as Second Language. International Journal of Humanities and Social Science Invention, 6(9), 36-44.

Rahmiza, S. M., Adlim, \& Mursal. (2015). Pengembangan LKS STEM (Science, Technology, Engineering and Mathematics) dalam Meningkatkan Motivasi dan Aktivitas Belajar Siswa SMA Negeri 1 Beutong pada Materi Induksi Elektromagnetik. Jurnal Pendidikan Sains Indonesia, 3(1), 239-250.

Rokhman, F., \& Yuliati. (2010). The Development of The Indonesian 
Izzah et al. - Analisis Effect Size Pengaruh ...

Teaching Material Based On Multicultural Context by Using Sociolinguistic Approach At Junior High School. Procedia Social and Behavioral Sciences, 1481-1488.

Roth, K. J., Bintz, J., Wickler, N. I., Hvidsten, C., Taylor, J., Beardsley, P. M., ... \& Wilson, C. D. (2017). Design principles for effective video-based professional development. International Journal of STEM Education, 4(1), $1-24$.

Shahali, E. H. M., Halim, L., Rasul, M. S., Osman, K., \& Zulkifeli, M. A. (2016). STEM learning through engineering design: Impact on middle secondary students' interest towards STEM. EURASIA Journal of Mathematics, Science and Technology Education, 13(5), 1189-1211.

Sinaga, P., Suhandi, A., \& Liliasari. (2015). The Effectiveness of Scaffolding Design in Training Writing Skills Physics Teaching Materials. International Journal of Instruction, 8(1), 19-34.

Standish, N., Christensen, R., Knezek, G., Kjellstrom, W., \& Bredder, E. (2016). The effects of an engineering design module on student learning in a middle school science classroom. International Journal of Learning, Teaching and Educational Research, 15(6).

Sukma, M. (2018). Pengaruh Pendekatan STEM (Science, Technology, Engineering, Mathematics) Terhadap Pengetahuan, Sikap dan Kepercayaan. Prosiding Seminar
Nasional MIPA IV (hal. 180-186). Banda Aceh: Unsyiah.

Sulistiyowati, Abdurrahman, \& Jalmo, T. (2018). The Effect of STEM-Based Worksheet on Students' Science Literacy. Journal of Education and Teacher Training, 3(1), 89-96.

Taufiq, M., Muntamah, S., \& Parmin. (2019). Remediation of Misconception on Straight Line Motion Concept Using Guided Inquiry Model Assisted by Student Worksheet Based on Science, Technology, Engineering and Mathematics (STEM) on Junior High School. Journal of Physics : Conference Series (hal. 1-5). Semarang: IOP Publishing.

Wanda, A. N., \& Syafi'ah, R. (2020). Pengembangan Buku Ajar Bioteknologi Berbasis Science, Technology, Engineering and Math (STEM) untuk Meningkatkan High Order Thinking Skill (HOTS) Mahasiswa. Jurnal Program Studi Pendidikan Biologi, 10(2), 1-9.

Widayanti., Abdurrahman., \& Suyanta, A. (2019). Future Physics Learning Materials Based on STEM Education : Analysis of Teachers and Students Perceptions. Journal of Physics : Conference Series (hal. 1-9). Lampung: IOP Publishing.

Widoyoko, A., Latifah, E., \& Yulianti, L. (2018). Peningkatan Kompetensi Literasi Saintifik Siswa SMA dengan Bahan Ajar Terintegrasi STEM pada Materi Impuls dan Momentum. Jurnal 
Izzah et al. - Analisis Effect Size Pengaruh ...

Pendidikan : Teori, Penelitian dan

Pengembangan, 3(11), 1463-1467.

Yuli, V. E. (2019). Development of STEM (Science, Technology, Engineering, Mathematics) Integrated Encyclopedia as

Enrichment for Students in

Elementary Schools. Jurna;

Inovasi Pendidikan Dasar, 5(1), 31-44. 